basis on which such a system must work. The senate, which is just appointed, is ( $\mathrm{m}$ powered, be it observed, to grant degrees in medicine. Already does the new charter secure to the teachers in the medical department of King's College, that the matrieulation tickets of their pupils shall entitle the candidates to be examined by the senate in the new University. Now, this advantage is conferred upon a medical school, which, probably, with only one exception, is the least efficient, is the worst, in London. Why, then, is that place preferred? Because the lectures are delivered in a pompous pile of buildings, and because it enjoys the patronage of the aristocracy. We are bound, therefore, to declare that the selection of such an establishment as the medical cepartment of King's College, on this occasion, reflects discredit either on the mo ives or on the judgment of the advisers of the Crown, and holds out an example to the senate, which may be adopted, in many instances, to the exclusion of the most gifted of our students from the honours and rewaids of the new University, and to the irreparable injury of a majority of our private teachers in medicine.

\section{MEDICAL WITNESSES ACT.}

\section{To the Editor of The LANCET.}

SIR:-We have great pleasure in bearing testimony to the success of the Medical Witnesses Act in this town. The legal fee was immediately paid to us by the overseer of the parish, on the production of the coroner's order. The inquest was held Dec.3rd. 'We think that it was the first order issued under the new Act here. We are your obedient servants,

\section{Colchester, Dec. 12, $18: 6$.}

SIR :-I should have replied before to your enquiries relative to the operation of the Medical Witnesses Act, but I was not able to obtain the requisite information for some days after receiving your letter.

$I$ find that only one of the surgeons of the Union has been called in to give evidence at inquests since the Act came into operation: and of two which he has attended, he re- ceived on each occasion an order from the coroner for the guinea fee. One was paid, I believe, at once, but on the second some difficulty arose as to what parish was liable. No objection, however, has been made to complying with the provisions of the Act (so far as 1 have been able to learn) in any one instance. I am, Sir, your obedient ser. vant,

5, Hammet-street, Taunton,

H. AlFoRd. Dec. 12, 1836.

\section{MEETING AT SOUTHAMPTON.}

\section{To the Editor of THE LANCET.}

Srn:--You will probably be furnished with a report of the proceedings of a meet. ing of medical gentlemen which was held at Southampton on the 20th of Norember, to establish a branch of the Provincidil Medical and Surgical Association in the Southern division of England. I do not know what title you may be pleased to pat to the report, but $I$ would suggest one to be drawn from the chief promoters' own epithets, employed in their speeches. I can assure you that if derived from those sources it would be not less correct than candid, and more explanatory than any other. It might, then, stand thus:-

"AN ASSOCIATION FOR EXTENDING AND ENFORCING

THE HOMAGE DUE FROM HUMBLE AND IMPOTENT BRITISH MEDI. CAL PRACTITIONERS,

TO THEIR LORDS AND MASTERS OF THE

PROVINCIAL HOSPITALS,

AND THE DUBS AND PURES IN GENERAL."

In framing such a title for the meeting no draught, I say, need be made on the fancy or imagination. These terms were suppled in speeches which afferded abundant evidence that the $W_{\text {orcester-W }}$ inchester-Chichester scheme has been concocted to decoy the southern "subordinates" into the payment of an annual homage and fealty to the "great and distinguished shepherds" of tlie profession, at Winchester, Chichester, An* dover, Portsmouth, or other southern county. Nothing more than such a title, and a reperusal of your just and acute remarks in The La ncet of July 30 , on the designs of the Parent "Migratory" Association, can be necessary to open any half-closed eyes of attendants at the meeting, to the real objects of the bombastically-extolled "branch," and I do trust that those gentlemen who may have been momentarily delud ed on that occasion will refrain, on their return, from attempting to persuade their professional 